\title{
The Use of Analytical Isoelectric Focusing for Detection and Identification of $\beta$-Lactamases
}

\author{
By MARGARET MATTHEW, ANNE M. HARRIS, \\ MONICA J. MARSHALL AND G. W. ROSS \\ Microbiology Department, Glaxo Research Ltd, Greenford UB6 OHE, Middlesex
}

(Received 20 December 1974)

\begin{abstract}
SUMMARY
$\beta$-Lactamases (EC. 3.5.2.6) from strains of Gram-negative bacteria have been studied using analytical isoelectric focusing. This permits a visual comparison of the patterns of $\beta$-lactamase bands produced by enzymes from different organisms. Purification of crude intracellular preparations is unnecessary and the technique is sufficiently sensitive to demonstrate $\beta$-lactamase in mutants previously reported to lack the enzyme. R factor RTEM and RPI $\beta$-lactamases that have not been distinguished from one another biochemically or immunologically can be differentiated by isoelectric focusing. Conversely, the enzymes specified by the $\mathrm{R}$ factors RTEM, $R_{I}$ and $R_{\text {GN14 }}$, with identical isoelectric focusing patterns, have the same biochemical properties. Chromosomal and $\mathbf{R}$ factor-mediated $\beta$-lactamases from single strains have been separated and their identities confirmed by immunoisoelectric focusing. $\mathbf{R}$ factor-mediated enzymes gave identical isoelectric focusing patterns irrespective of the host strain. Isoelectric focusing can therefore be used to observe the transfer of $\beta$-lactamases carried by $\mathbf{R}$ factors.
\end{abstract}

\section{INTRODUCTION}

Isoelectric focusing (Haglund, 1967) is a method of separation in which proteins align themselves as sharp bands at their isoelectric points (pI) in an electrophoretically-produced $\mathrm{pH}$ gradient. A high degree of resolution is obtained by the method, because focusing is caused by forces that act against diffusion and proteins are therefore concentrated during their separation. We have used the technique in the analytical mode for the separation of $\beta$-lactamases (EC. 3.5.2.6) on thin layers of polyacrylamide gel and have located the focused enzymes with a cephalosporin substrate which changes colour after degradation by $\beta$-lactamase. This technique of separation and specific staining of $\beta$-lactamases allows demonstration of low levels of activity and presents the different enzymes produced by various strains as patterns of bands that can easily be recognized and compared.

The $\beta$-lactamases produced by Gram-negative bacteria are known to differ in their substrate specificities, inhibitor profiles, electrophoretic mobilities, biochemical properties and reactions with antisera (Hamilton-Miller, 1967; Jack \& Richmond, I970; O'Callaghan \& Morris, I972; Richmond \& Sykes, I973; Yamagishi et al. 1969). These enzymes have frequently been classified by the relative rates at which they hydrolyse penicillins and cephalosporins. Various methods have been used for estimating the activity of crude and pure enzyme preparations, and when a single strain produces two $\beta$-lactamases these have not always been separated before determining the substrate profile. Comparison of profiles determined in different laboratories may therefore be misleading. The use of isoelectric focusing of $\beta$-lactamases for direct comparison of different enzymes has been illustrated in 


\begin{tabular}{|c|c|c|c|}
\hline Organism & Strain no. & Derivation of strains & Reference \\
\hline \multirow[t]{10}{*}{ Escherichia coli } & D3 I & KI 2, RC7 I I derivative & Burman, Nordström \& Boman $\dagger$ (I 968) \\
\hline & TEM & KI 2 (RTEM) & Datta \& Kontomichalou (1965) \\
\hline & $\mathbf{R}_{\mathrm{GN} 238}$ & $\mathrm{~K} 12, \mathrm{w}_{3} 630\left(\mathrm{R}_{\mathrm{GN} 238}\right)$ & Sawai, Mitsuhashi \& Yamagishi† (1968) \\
\hline & $\mathbf{R}_{\mathrm{GN14}}$ & K I 2, W3630 ( $\left.\mathrm{R}_{\mathrm{GN14}}\right)$ & Sawai et al. (1968) \\
\hline & RI $8 I 8$ & $\mathrm{~K} I 2, \mathrm{~J} 53(\mathrm{I} 8 \mathrm{1} 8)$ & Datta $\uparrow \&$ Kontomichalou (1965) \\
\hline & RI & KI 2, RC7II (RI) & Meynell \& Datta $†$ (I966) \\
\hline & RPI-I & KI 2, W3I IO (RPI-I) & Sykes $\dagger \&$ Richmond (1970) \\
\hline & RPI-I* & KI2, W3IIO (RPI-I*) & Richmond \& Sykes $\dagger$ (1972) \\
\hline & KI 2-44 & $\mathrm{KI} 2,44$ & $\begin{array}{l}\text { Nguyen-Distèche, Pollock, Ghuysen } \dagger \text {, } \\
\text { Puig, Reynolds, Perkins, Coyette \& } \\
\text { Salton (I973) }\end{array}$ \\
\hline & Hlt4 & $\begin{array}{l}\text { Transductant from Hit3 } \\
\text { using TPI phage }\end{array}$ & $\begin{array}{l}\text { Burman, Park, Lindström \& Boman† } \\
\text { (1973) }\end{array}$ \\
\hline \multirow[t]{2}{*}{ Klebsiella aerogenes } & IO82E & Clinical isolate & Marshall $\dagger$ et al. (1972) \\
\hline & I $478 \mathrm{E}$ & Clinical isolate & Newsom, $\dagger$ Marshall \& Harris (1974) \\
\hline \multirow[t]{4}{*}{ Enterobacter cloacae } & P99 & Blood culture & Fleming, $\dagger$ Goldner \& Glass (1963) \\
\hline & I32IE & $\begin{array}{l}\text { Spontaneous mutant of } \\
\text { Ent. cloacae } \mathrm{P} 99\end{array}$ & Goldner, Glass \& Fleming† (1969) \\
\hline & 2 I 4 & Clinical isolate & Hennessey $\dagger(1967)$ \\
\hline & $1685 \mathrm{E}$ & Clinical isolate & Newsom $†$ et al. (I974) \\
\hline Proteus mirabilis & I $496 \mathrm{E}$ & Wound swab & Newsom† et al. (I974) \\
\hline Proteus rettgeri & $1728 \mathrm{E}$ & Sputum sample & Newsom $\dagger$ et al. (1974) \\
\hline $\begin{array}{l}\text { Pseudomonas } \\
\text { aeruginosa }\end{array}$ & RPI & Clinical isolate & Richmond \& Sykes † (I972) \\
\hline
\end{tabular}

this paper principally by reference to enzymes from Escherichia coli. This species was chosen because strains carrying $\mathbf{R}$ factors specifying well-characterized $\beta$-lactamases were available.

\section{METHODS}

Strains. These are listed in Table I. The clinical isolates were identified by the methods of Cowan \& Steel (1965). Other strains of Gram-negative and Gram-positive bacteria were also examined. These were taken from the culture collection maintained in this laboratory.

Resistance transfer. The presence of $\mathbf{R}$ factors specifying resistance to $\beta$-lactam antibiotics was verified using the method of Datta (I962). Escherichia coli KI 2 cultures, either NC I B 270 or NCIB9482, resistant to nalidixic acid or streptomycin, were used as recipients.

Preparation of intracellular enzymes. Organisms were grown in $50 \mathrm{ml}$ volumes of brainheart infusion broth (Difco) and harvested as described by Marshall et al. (1972). Cells were resuspended in water to a final concentration of $10^{9} / \mathrm{ml}$. Intracellular enzymes were released by ultrasonic treatment (Ross \& Boulton, 1973).

Sand-grinding was used as an alternative method of releasing intracellular enzymes. Cell suspensions, in $5 \mathrm{ml}$ amounts, were ground with sand. Sand and cell debris were removed by centrifugation at $5000 \mathrm{~g}$ for $30 \mathrm{~min}$. Some enzymes with low activity were concentrated by freeze-drying. The $\beta$-lactamases from $E$. coli TEM and Enterobacter cloacae 999 were partly purified using Sephadex G-50 and purified further on QAE-Sephadex (Ross \& Boulton, 1973).

Chemicals. Acrylamide, $N, N^{\prime}$-methylenebisacrylamide and riboflavin were obtained from BDH, $N, N, N^{\prime}, N^{\prime}$-tetramethylethylenediamine from Eastman Organic Chemicals, Rochester, 
New York, U.S.A., and pH 3.5 to Io ampholine from LKB Instruments Ltd, South Croydon, Surrey.

Analytical isoelectric focusing. This was carried out on sheets of polyacrylamide gel $(2 \mathrm{I} .5 \times 16.5 \times 0.15 \mathrm{~cm})$ supported on glass plates (Awdeh, Williamson \& Askonas, I 968 ; Salaman \& Williamson, 1971). The composition of the gel mixture was as follows: acrylamide, $70 \mathrm{mg} / \mathrm{ml} ; N, N^{\prime}$-methylenebisacrylamide, $2 \mathrm{mg} / \mathrm{ml} ; N, N, N^{\prime}, N^{\prime}$-tetramethylethyl-

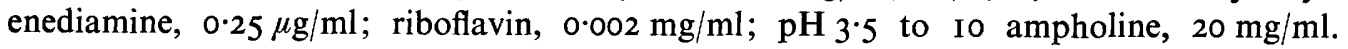
Samples (up to $50 \mu \mathrm{l}$ ) were applied near the anode as drops of liquid on the surface of the gel. Isoelectric focusing was carried out at 100 to $400 \mathrm{~V}$ for about $40 \mathrm{~h}$. As soon as the current had been switched off, the $\mathrm{pH}$ gradient of the gel was read at $0.5 \mathrm{~cm}$ intervals from the cathode to the anode using a miniature flat-ended combined glass electrode (PyeUnicam 403.30 $\mathrm{M} 8 \mathrm{EO}_{7}$ ). The diameter of the electrode is $5 \mathrm{~mm}$, compared with a band width of $\mathrm{I} \mathrm{mm}$ or less, so that the $\mathrm{pI}$ recorded for a given band could vary by a $\mathrm{pH}$ value of \pm 0.2 from run to run. Each pI value given in this paper is the mean of sixteen or more values determined after different electrofocusing runs. After the $\mathrm{pH}$ measurements had been recorded, the gel was stained for $\beta$-lactamase activity and photographed.

Staining gels for $\beta$-lactamase activity. The enzyme was usually detected by using a chromogenic cephalosporin as substrate (O'Callaghan et al. 1972). This compound, 3-(2,4-dinitrostyryl)-(6R, $7 \mathrm{R})-7 \beta$ (2-thienylacetamido)-ceph-3-em-4-carboxylic acid, E-isomer, will be referred to as cephalosporin 87/312. A sheet of Whatman No. 54 paper which had been dipped in a solution of cephalosporin $87 / 312(0.5 \mathrm{mg} / \mathrm{ml}$ in $0.1 \mathrm{M}$-phosphate buffer, $\mathrm{pH} 7 \cdot 0)$ was laid over the surface of the gel and then removed, in one continuous rotary motion. The intact substrate molecule is yellow, but becomes pink when the $\beta$-lactam bond is broken, so that focused bands with $\beta$-lactamase activity appear pink on a yellow background. In some instances, enzyme activity was also detected by the starch-iodine method of Perret (1954), as modified by Ross \& Boulton (I972), using benzyl penicillin or cephalosporin C (I0 $\mathrm{mg} / \mathrm{ml}$ ) as substrate.

Staining gels for protein. Gels were immersed for I h in Coomassie brilliant blue G $(0.1 \%$, $\mathrm{w} / \mathrm{v})$ dissolved in ethanol-acetic acid-water (35:10:55, by vol.). They were destained in ethanol-acetic acid-water (30:5:65, by vol.).

Photography. A record of the results could be obtained only if the plates were photographed. The pink bands associated with $\beta$-lactamase activity could not be fixed and the faint pink lines on a yellow background could not be distinguished readily. When a focused gel was treated with cephalosporin 87/3I 2 the $\beta$-lactamase bands appeared gradually and by the time the weakest bands were visible, the strongest bands had diffused. Serial photographs were usually taken to obtain a complete record. Kodalith Ortho film $(35 \mathrm{~mm})$ was used with transmitted light and a Wratten 58 green filter. The film was processed in PQ developer for $5 \mathrm{~min}$ at $2 \mathrm{I}{ }^{\circ} \mathrm{C}$ and prints were made, enlarged six times. Relatively early photographs have been used in the Figures as these showed the maximum number of clearly defined main bands.

Preparation of antisera. Antiserum against purified TEM $\beta$-lactamase (Jack \& Richmond, 1970) was provided by R. B. Sykes. Antisera to $\beta$-lactamases from Ent. cloacae P99 (Ross \& Boulton, 1972) and E. coli D3I, purified by the method described for P99 enzyme (Ross \& Boulton, 1973) were provided by M. G. Boulton.

Immunoisoelectric focusing. Using a Perspex former, six troughs $(\mathrm{I} 65 \times \mathrm{I} \cdot 0 \mathrm{~mm})$ were set into a sheet of polyacrylamide gel on which samples were focused. Antiserum was then added to the troughs. The gel was incubated at $4{ }^{\circ} \mathrm{C}$ in a humid atmosphere for 7 days to allow precipitin arcs to form. These were stained for $\beta$-lactamase activity. 


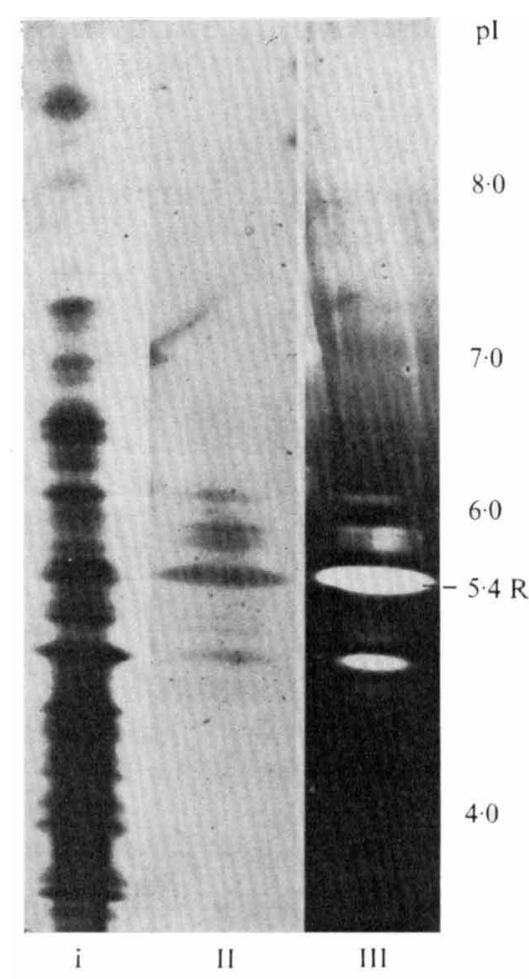

Fig. I

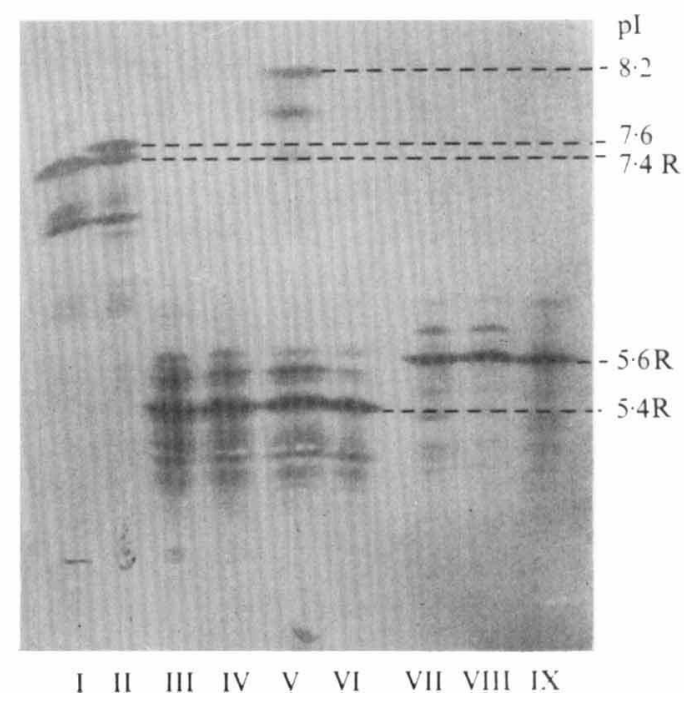

Fig. 2

Fig. I. An intracellular preparation of $E$. coli TEM stained with: I, Coomassie blue G; II, cephalosporin $87 / 312$; III, benzyl penicillin and starch-iodine. R denotes a band of $\beta$-lactamase mediated by an $\mathbf{R}$ factor.

Fig. 2. The $\beta$-lactamases specified by strains carrying $\mathrm{R}$ factors in hosts of different genera. Preparations of the following strains were focused: I, E. coli $\mathrm{R}_{\mathrm{GN} 238}$; II, Klebsiella aerogenes $\mathrm{I} 478 \mathrm{E}$; III, Proteus rettgeri I728E; IV, P. mirabilis I496E; V, Ent. cloacae I685E; VI, E. coli TEM; VII, E. coli RPI-I; VIII, E. coli RPI-I*; IX, Pseudomonas aeruginosa RPI. The presence of a transmissible R factor mediating resistance to $\beta$-lactam antibiotics was confirmed in every strain except $E$. coli RPI-I*. In this organism the R factor had become integrated in the chromosome.

\section{RESULTS}

The method of detecting and identifying $\beta$-lactamases by analytical isoelectric focusing

In focused intracellular preparations, cephalosporin 87/3 2 stained $\beta$-lactamase, revealing patterns of bands qualitatively identical to the patterns revealed by starch-iodine staining, and radically different from the protein bands (Fig. I). $\beta$-Lactamase bands were usually detected with cephalosporin 87/3 I 2 because starch-iodine-stained gels faded quickly above $\mathrm{pH} 8$ and gave poor definition of bands with high pI values. Using cephalosporin 87/3I2, about 0.0002 i.u. $\beta$-lactamase could be detected on the focused gel. By taking sequential photographs, samples with a $16000-$ fold range of activity could be compared on a single plate.

A $\beta$-lactamase pattern could contain several groups of bands (Fig. 2, V); each group of bands usually consisted of one main band and a number of satellite bands (Fig. 2, V, main bands with pI 8.2 and $5.4 \mathrm{R}$, where $\mathrm{R}$ denotes a band of $\beta$-lactamase mediated by an $\mathrm{R}$ factor). The patterns could always be reproduced when replicate experiments were carried 


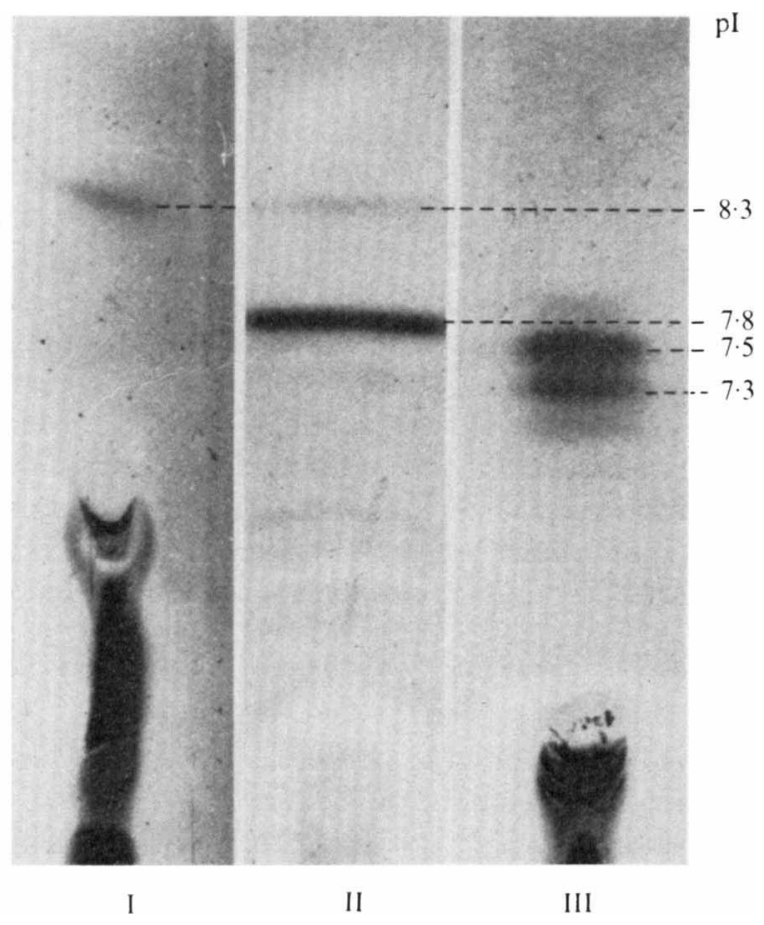

Fig. 3. Bands with $\beta$-lactamase activity from intracellular preparations of $\beta$-lactamase-negative mutants: I, E. coli $\mathrm{HI}$ t4; II, E. coli $\mathrm{KI} 2-44$; III, Ent. cloacae I $32 \mathrm{IE}$.

out. The intensities of the bands shown in the Figures were not related quantitatively to the amounts of enzyme produced by the organisms, because loadings of enzyme were adjusted so that a qualitative comparison could be made between the principal $\beta$-lactamase bands of different patterns. .

The same isoelectric focusing patterns were obtained from intracellular preparations of an organism broken by ultrasonic waves or sand-grinding, and from enzyme that had been partly purified by passing the crude preparation through Sephadex G-50 (Ross \& Boulton, 1973). When the $\beta$-lactamases from Klebsiella aerogenes $1082 \mathrm{E}$ and Ent. cloacae $\mathrm{P} 99$ and 2I4 were further purified on QAE-Sephadex (Ross \& Boulton, I973), their isoelectric focusing patterns differed from those of crude intracellular preparations from the same strains only in the relative intensities of a few of the satellite bands. Experiments were carried out to establish whether the satellite bands were artefacts produced by the conditions of isoelectric focusing. Identical isoelectric focusing patterns were usually obtained when samples were loaded at different ends of the gel, samples were loaded on to different concentrations of ampholine, and when crude sand-ground preparations or partly purified preparations were run. Individual bands, when focused a second time, always appeared in the same positions relative to one another. Enzymes were considered to be identical when the main and satellite bands were confluent, e.g. the confluent main bands (pI 5.4R) and satellites in Fig. 2, III to VI. 


\section{The use of isoelectric focusing to detect $\beta$-lactamase in $\beta$-lactamase-negative strains}

A number of authors have isolated mutant strains in which they were unable to detect $\beta$-lactamase. We examined three such strains (Table $\mathrm{r}$ ) and found that bands of $\beta$-lactamase activity could be demonstrated after focusing the intracellular preparations (Fig. 3). Two mutants of $E$. coli $\mathrm{KI} 2, \mathrm{HI}_{4}$ and $\mathrm{KI}_{2}-44$, each had a band (pI 8.3) that appeared to be identical with the main band of the $\beta$-lactamase from another strain of E. coli KI 2, D3I. Strain KI 2-44 had an additional and stronger band with pI $7 \cdot 8$. It has been suggested (J.-M. Ghuysen, personal communication) that the $\mathrm{pI} 7.8$ band might be membrane-bound DD-carboxypeptidase-transpeptidase that had been solubilized by ultrasonic treatment in the same way as the corresponding Streptomyces enzyme (Frère et al. 1974). $\beta$-Lactamase from a spontaneous mutant (I32IE) of Ent. cloacae had a doublet of bands (pI 7.3, 7.5) compared with pI 8.0 for $\beta$-lactamase 899 from the parent strain. Bands of $\beta$-lactamase activity have also been seen after focusing intracellular preparations from Haemophilus, Neisseria and Streptococcus spp. that were previously thought not to produce the enzyme.

\section{The use of isoelectric focusing to distinguish between $\beta$-lactamases from Escherichia coli}

Strains of $E$. coli have been reported to produce a variety of $\beta$-lactamases that differ in their biochemical properties (Richmond \& Sykes, 1973). Several of these enzymes are known to be $\mathbf{R}$ factor-mediated. The isoelectric focusing patterns from seven strains of E. coli KI2 were examined (Fig. 4). All preparations had a band at pI 8.3. This band, with its satellites, was the only band seen in the pattern for E. coli D3I (Fig. 4, I), a strain that produces a chromosomally-mediated $\beta$-lactamase (Boman, Eriksson-Grennberg, Normark \& Matsson, 1968). Bands at pI 8.3 from the other six strains were confluent with the D3I band when they were compared in adjacent tracks, and were considered to be identical. This finding suggests that the $\beta$-lactamase bands which focus at pI 8.3 are chromosomally specified in strains of $E$. coli KI2. The same band has also been seen in 104 other strains of $E$. coli $\mathrm{KI} 2$ carrying various $\mathrm{R}$ factors. The $\beta$-lactamase band at $\mathrm{pI} 8.3$ is not clearly visible for all the strains shown in Fig. 4, because it is difficult to obtain a goød simultaneous picture of two groups of isoelectric focusing bands present in a single preparation.

In addition to groups of bands at $\mathrm{pI} 8 \cdot 3$, the focusing patterns of all six strains carrying $\mathbf{R}$ factors had a second group of bands that were shown by transfer experiments to be $\mathbf{R}$ factor-associated (Fig. 4, II to VII). In the patterns of all strains of $E$. coli carrying R factors, the bands associated with $\mathrm{R}$ factor were more strongly expressed than the bands at $\mathrm{pI} 8 \cdot 3$. Strains carrying the $\mathrm{R}$ factors $\mathrm{RTEM}, \mathrm{RI}_{\mathrm{I}}$ and $\mathrm{R}_{\mathrm{GN14}}$ produced the group of bands (main band pI 5.4R) seen in Fig. 4, II to IV. The enzymes mediated by these $R$ factors have previously been reported to have similar biochemical properties (Dale \& Smith, 197I; Richmond \& Sykes, 1973; Yamagishi et al. 1969), and the confluence of main and satellite bands in focusing patterns from these strains confirms that the enzymes are identical.

The association of RTEM-mediated activity with the pI 5.4 R main band was confirmed by immunoisoelectric focusing against antiserum to $E$. coli TEM $\beta$-lactamase (Fig. 5, II). Bands at pI $5.4 \mathrm{R}$ cross-reacted with TEM antiserum but not with antiserum to $E$. coli D3 I $\beta$-lactamase. Similarly, the band at pI $8 \cdot 3$ did not cross-react with TEM antiserum (Fig. $5, \mathrm{I}$ ). TEM $\beta$-lactamase could be detected by isoelectric focusing when it was produced in different genera, e.g. two species of Proteus, Ent. cloacae I685E and E. coli TEM. Figure 2 (III to VI) shows the confluent bands at $\mathrm{pI} 5 \cdot 4 \mathrm{R}$ associated with the TEM enzyme.

The isoelectric focusing pattern of a preparation of Ent. cloacae $1685 \mathrm{E}$ contained two 


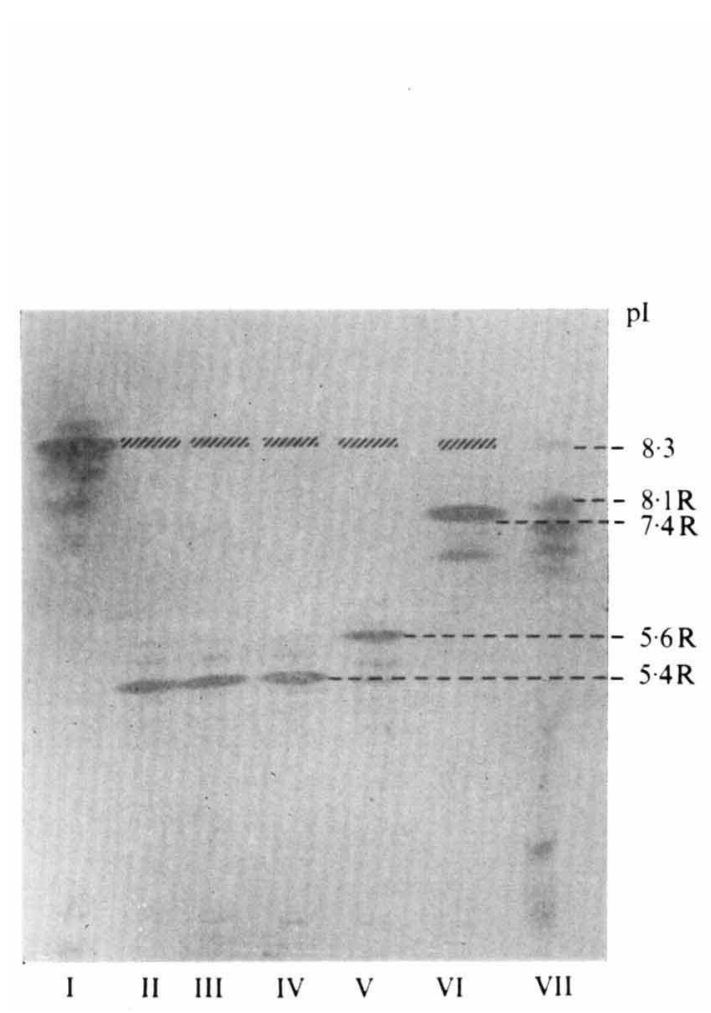

Fig. 4

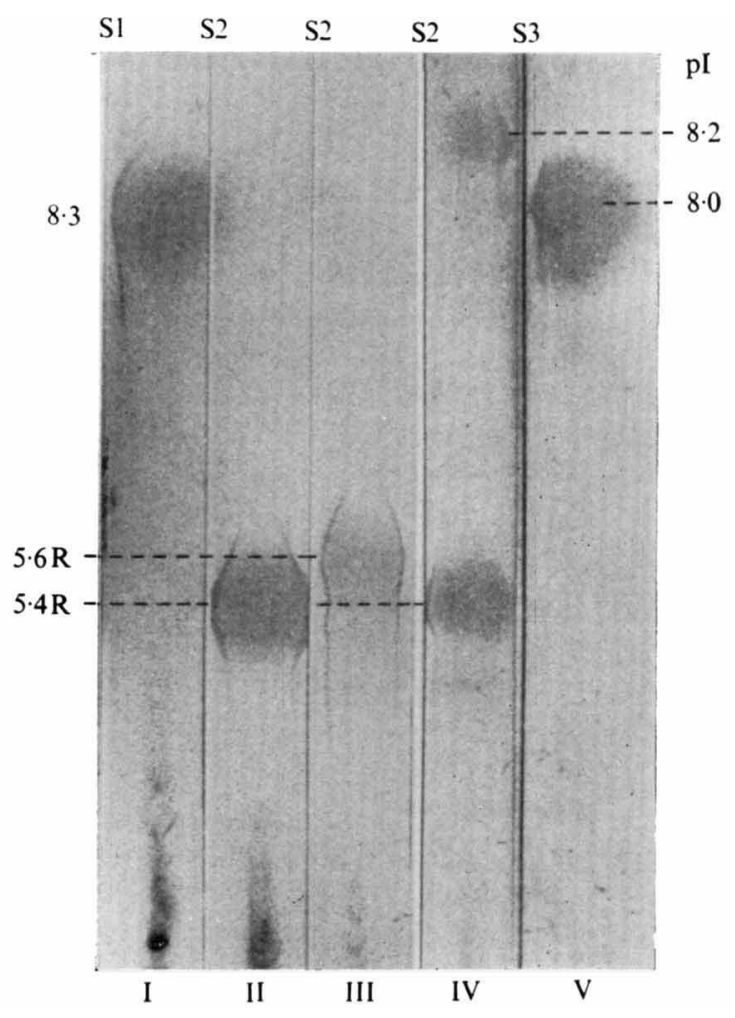

Fig. 5

Fig. 4. The separation of $\beta$-lactamases from E. coli. Preparations from the following strains were

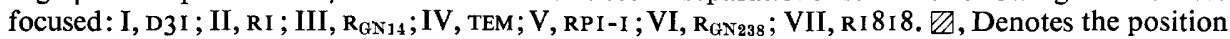
of weaker bands that developed slowly and which are seen in later serial photographs.

Fig. 5. Immunoisoelectric focusing of $\beta$-lactamases. Preparations from the following strains were focused: I, E. coli D3I ; II, E. coli TEM; III, E. coli RPI-I ; IV, Ent. cloacae I685E; V, Ent. cloacae P99. Troughs were filled with: SI, antiserum to purified D3 I enzyme; S2, antiserum to purified TEM enzyme; S3, absorbed antiserum to Ent. cloacae P99 enzyme. Tracks I to III and IV to V were run on separate plates.

groups of $\beta$-lactamase bands (Fig. 2, V; main bands, pI $8 \cdot 2$ and $5.4 \mathrm{R}$ ). These cross-reacted, respectively, with antiserum to Ent. cloacae P99 enzyme and to the TEM enzyme (Fig. 5, IV). These findings indicate that the $\beta$-lactamase at $\mathrm{pI} 8 \cdot 2$ was specified by an Ent. cloacae gene and the $\beta$-lactamase at $\mathrm{pI} 5 \cdot 4 \mathrm{R}$ by a gene associated with the TEM $\mathrm{R}$ factor.

The RPI R factor which originated in a strain of Pseudomonas gives rise to an enzyme identical (Sykes \& Richmond, 1970) to the $\beta$-lactamase from $E$. coli TEM in its substrate specificity, molecular weight and cross-reaction with antiserum to purified TEM enzyme (Fig. 5, II and III). In spite of these similarities, the isoelectric focusing patterns of the enzymes were clearly different (Fig. 4, IV and V). The RPI-I R factor (RPI lacking the resistance markers neomycin and tetracycline) is also present in strain $E$. coli RPI-I*, but in this strain it has been integrated into the chromosome as a stable element (Richmond \& Sykes, I972). The isoelectric focusing patterns for the enzyme RPI were identical whether it was specified by a transmissible $\mathrm{R}$ factor in Pseudomonas or in E. coli $\mathrm{KI} 2$ or by the $\mathrm{R}$ factor integrated into the $E$. coli chromosome (Fig. 2, VII, VIII and IX).

Escherichia coli $\mathrm{R}_{\mathrm{G} \times 238}$ gave an isoelectric focusing pattern with a main band at $\mathrm{pI} 7 \cdot 4 \mathrm{R}$ 
(Fig. 4, VI) which was thought to be the R factor-mediated enzyme. No antiserum to this enzyme was available, but it did not cross-react with antisera to $E$. coli D3 I or TEM enzymes. An identical band at $\mathrm{pI} 7 \cdot 4 \mathrm{R}$ was seen in the electrofocusing pattern from a clinical isolate, Klebsiella aerogenes $\mathrm{I} 478 \mathrm{E}$ (Fig. 2, I and II). An R factor was transferred from this strain to $E$. coli $\mathrm{KI} 2$, and the resulting organism gave an electrofocusing pattern identical with that of $E$. coli $\mathrm{R}_{\mathrm{GN} 238}$. It was originally suggested (Dale, I97I) that the $\mathrm{R}_{\mathrm{GN} 238}$ and $\mathrm{RI} 8 \mathrm{I} 8 \beta$ lactamases were the same, but they were later differentiated by molecular weight and enzyme kinetic experiments (Dale \& Smith, I972). For the purpose of this study R I 8 I 8 was transferred to $E$. coli KI2. Isoelectric focusing confirms that the $\mathrm{R}_{\mathrm{GN} 238}$ and RI8I8 enzymes are different (Fig. 4, VI and VII).

\section{DISCUSSION}

Analytical isoelectric focusing has shown that three $\beta$-lactamase-negative mutants do produce $\beta$-lactamase, although the isoelectric point is sometimes different from that of the corresponding wild-type enzyme.

A $\beta$-lactamase generally focuses as a main band that is accompanied by satellite bands. The close relationship between these is demonstrated by the multiple-linking arcs they give in immunoisoelectric focusing against antiserum to a highly purified enzyme preparation. This sort of microheterogeneity does not seem to be the type of artefact that commonly arises in isoelectric focusing (Carlström \& Vesterberg, 1967; Frater, 1970; Illingworth, 1972) because it is unaffected by altering the experimental conditions. It is also unlikely that the microheterogeneity is caused by the action of the local intracellular environment on the enzyme, because a $\beta$-lactamase mediated by an $\mathbf{R}$ factor has an identical isoelectric focusing pattern when it is isolated from hosts of different genera. Post-synthetic deamidation gives rise to microheterogeneity (Awdeh, Williamson \& Askonas, 1970), but of a distinctive pattern, quite different from the patterns observed for $\beta$-lactamases. At present, the reason why an apparently single $\beta$-lactamase focuses as a main band accompanied by satellites is unknown.

Since the different $\beta$-lactamases produced by $\mathrm{R}$ factors can easily be recognized by analytical isoelectric focusing, this method can be used in epidemiological studies for identifying the enzyme responsible for the acquired resistance of a strain. It clearly distinguishes between the TEM and RPI enzymes that had not previously been distinguished either biochemically or immunologically. Another potential use of the technique is to demonstrate the presence of $\mathbf{R}$ factors specifying $\beta$-lactamase in genera such as Proteus, in which expression of the gene is impaired (Smith, 1969). The patterns of the $\beta$-lactamase specified by the RPI-I R factor existing as a transmissible plasmid or integrated into the chromosome are identical. It is therefore impossible to say whether an enzyme is chromosomally or $\mathrm{R}$ factor-mediated unless the necessary genetic experiments have been done to prove $\mathrm{R}$ factor or chromosomal transfer. Isoelectric focusing could also be used for observing the transfer, between species, of plasmids that specify $\beta$-lactamases and presumably applied to other $\mathrm{R}$ factor-specified enzymes, such as those that inactivate aminoglycosides.

Identical isoelectric focusing patterns are given by the $\beta$-lactamases specified by $\mathbf{R}$ factors TEM, RI and $\mathrm{R}_{\text {GN14 }}$, which appear to have identical biochemical properties. It therefore seems probable that one can predict the properties of a $\beta$-lactamase if its isoelectric focusing pattern is identical with that of an enzyme that has already been characterized. The question as to whether $\beta$-lactamases are elicited in response to $\beta$-lactam antibiotics or are enzymes that play a fundamental role in normal bacterial physiology is still unanswered. The latter alternative is supported by the detection of $\beta$-lactamases in a wide range of bacteria. To 
date, the enzyme has been found, using analytical isoelectric focusing, in 354 strains from I9 genera.

We thank S. R. Jones for taking the photographs, and Janet E. Horne and P. R. Adams for technical assistance.

\section{REFERENCES}

Awdeh, Z. L., Williamson, A. R. \& Askonas, B. A. (I968). Isoelectric focusing in polyacrylamide gel and its application to immunoglobulins. Nature, London 219, 66-67.

Awdeh, Z. L., Williamson, A. R. \& Askonas, B. A. (1970). One cell - one immunoglobulin: origin of limited heterogeneity of myeloma proteins. Biochemical Journal I16, $24 \mathrm{I}-248$.

Boman, H. G., Eriksson-Grennderg, K. G., Normark, S. \& Matsson, E. (I968). Resistance of Escherichia coli to penicillins. IV. Genetic study of mutants resistant to D,L-ampicillin concentrations of $100 \mu \mathrm{g} / \mathrm{ml}$. Genetical Research 12, I69-185.

Burman, L. G., Nordström, K. \& Boman, H. G. (1968). Resistance of Escherichia coli to penicillins. V. Physiological comparison of two isogenic strains, one with chromosomally and one with episomally mediated ampicillin resistance. Journal of Bacteriology 96, 438-446.

Burman, L. G., Park, J. T., Lindström, E. B. \& Boman, H. G. (I973). Resistance of Escherichia coli to penicillins: identification of the structural gene for the chromosomal penicillinase. Journal of Bacteriology II6, I23-130.

CARLSTRÖM, A. \& VeSTeRberg, O. (1967). Isoelectric focusing and separation of the subcomponents of lactoperoxidase. Acta chemica scandinavica 2r, 27I-278.

Cowan, S. T. \& Steel, K. J. (1965). Identification of Medical Bacteria, pp. 76-82. Cambridge: Cambridge University Press.

DALE, J. W. (I97I). Characterization of the $\beta$-lactamase specified by the resistance factor RI8I8 in E. coli $\mathrm{K}-\mathrm{I} 2$ and other Gram-negative bacteria. Biochemical Journal I23, 501-505.

Dale, J. W. \& Smith, J. T. (197I). Some relationships between R-factor and chromosomal $\beta$-lactamases in Gram-negative bacteria. Biochemical Journal 123, 507-512.

Dale, J. W. \& SMITH, J. T. (I972). A direct comparison of two unusual R-factor-mediated $\beta$-lactamases. Biochemical Journal 128, I73-174.

DatTa, N. (1962). Transmissible drug resistance in an epidemic strain of Salmonella typhimurium. Journal of Hygiene 60, $30 \mathrm{I}-3 \mathrm{IO}$.

Datta, N. \& Kontomichalou, P. (1965). Penicillinase synthesis controlled by infectious R-factors in Enterobacteriaceae. Nature, London 208, 239-241.

Fleming, P. C., Goldner, M. \& Glass, D. G. (1963). Observations on the nature, distribution and significance of cephalosporinase. Lancet i, I 399-I $40 \mathrm{I}$.

FRATER, R. (1970). Artifacts in isoelectric focusing. Journal of Chromatography 50, 469-474.

Frère, J.-M., Ghuysen, J.-M., Reynolds, P. E., Moreno, R. \& Perkins, H. R. (I974). Binding of $\beta$-lactam antibiotics to the exocellular DD-carboxypeptidase-transpeptidase of Streptomyces R39. Biochemical Journal 173, 24I-249.

Goldner, M., Glass, D. G. \& Fleming, P. C. (1969). Spontaneous mutant with loss of $\beta$-lactamase in Aerobacter cloacae. Journal of Bacteriology 97, 961.

HAGLUND, H. (1967). Isoelectric focusing in natural pH gradients - a technique of growing importance for fractionation and characterization of proteins. Science Tools 14, I 7-23.

Hamilton-MilleR, J. M. T. (1967). Hydrolysis of cephalosporins by $\beta$-lactamases from Gram-negative bacteria. Nature, London 214, I 333-1 334.

HeNNESSEY, T. D. G. (1967). Inducible $\beta$-lactamase in Enterobacter. Journal of General Microbiology 49, $277-285$.

ILLINGWORTH, J. A. (1972). Anomalous behaviour of yeast isocitrate dehydrogenase during isoelectric focusing. Biochemical Journal 129, I $25-1$ I 30.

JACK, G. W. \& RICHMOND, M. H. (I970). A comparative study of eight distinct $\beta$-lactamases synthesized by Gram-negative bacteria. Journal of General Microbiology 6r, 43-6I.

Marshall, M. J., Ross, G. W., Chanter, K. V. \& Harris, A. M. (1972). Comparison of the substrate specificities of the $\beta$-lactamases from Klebsiella aerogenes I082E and Enterobacter cloacae P99. Applied Microbiology 23, 765-769. 
MeYnell, E. \& DattA, N. (I966). The relation of resistance transfer factors to the R-factor (sex-factor) of Escherichia coli KI 2. Genetical Research 7, I34-I40.

Newsom, S. W. B., Marshall, M. J. \& Harris, A. M. (1974). Enterobacteria, $\beta$-lactam antibiotics and $\beta$-lactamases in clinical practice. Journal of Medical Microbiology 7, 473-482.

Nguyen-Distèche, M., Pollock, J. J., Ghuysen, J.-M., Puig, J., Reynolds, P., Perkins, H. R., Coyette, J. \& SaLton, M. R. J. (1973). Sensitivity to ampicillin and cephalothin of enzymes involved in wall peptide cross-linking in Escherichia coli $\mathrm{KI} 2$, strain 44. European Journal of Biochemistry 4I, 457-463.

O'Callaghan, C. H. \& MorRis, A. (1972). Inhibition of $\beta$-lactamases by $\beta$-lactam antibiotics. Antimicrobial Agents and Chemotherapy 2, 442-448.

O'Callaghan, C. H., Morris, A., Kirby, S. M. \& Shingler, A. H. (1972). Novel method for detection of $\beta$-lactamases by using a chromogenic cephalosporin substrate. Antimicrobial Agents and Chemotherapy I, 283-288.

Perret, C. J. (I954). Iodometric assay of penicillinase. Nature, London 174, IOI 2-IOI 3.

Richmond, M. H. \& SYKes, R. B. (1972). The chromosomal integration of a $\beta$-lactamase gene derived from the P-type R-factor RPI in Escherichia coli. Genetical Research 20, 23I-237.

Richmond, M. H. \& Sykes, R. B. (1973). The $\beta$-lactamases of Gram-negative bacteria and their possible physiological role. Advances in Microbial Physiology 9, 31-88.

Ross, G. W. \& Boulton, M. G. (I972). Improvement of the specificity of an antiserum to $\beta$-lactamase by absorption with a mutant which does not produce the enzyme. Journal of Bacteriology I12, I435-1437.

Ross, G. W. \& Boulton, M. G. (1973). Purification of $\beta$-lactamases on QAE-Sephadex. Biochimica et biophysica acta 309, 430-439.

Salaman, M. R. \& Williamson, A. R. (I971). Isoelectric focusing of proteins in the native and denatured states. Biochemical Journal 122, 93-99.

Sawai, T., Mitsuhashi, S. \& Yamagishi, S. (I968). Drug resistance of enteric bacteria. XIV. Comparison of $\beta$-lactamases in Gram-negative rod bacteria resistant to $\alpha$-aminobenzyl penicillin. Japanese Journal of Microbiology 12, 423-434.

SмIтH, J. T. (1969). R-factor gene expression in Gram-negative bacteria. Journal of General Microbiology 55 , I09-1 20.

SyKes, R. B. \& Richmond, M. H. (1970). Intergeneric transfer of a $\beta$-lactamase gene between $P$ s. aeruginosa and E. coli. Nature, London 226, 952-954.

Yamagishi, S., O'Hara, K., Sawai, T. \& Mitsuhashi, S. (I969). The purification and properties of penicillin $\beta$-lactamases mediated by transmissible R-factors in Escherichia coli. Journal of Biochemistry 66, I I-20. 